\title{
Influence of Seed Treatment with Fungicides on Seed Quality of Chickpea cv. GBM 2
}

\author{
Basave Gowda ${ }^{1 *}$, Rajashekar Kasam ${ }^{2}$, S. R. Doddagoudar ${ }^{2}$, Vijaykumar Kurnalliker ${ }^{2}$, \\ Channabasavanna ${ }^{3}$ and A. S. M. V. Ravi ${ }^{4}$
}

${ }^{I}$ National Seed Project (Crops), Seed Unit, University of Agricultural Sciences, Raichur- 584104, Karnataka, India

${ }^{2}$ Department of Seed Science and Technology, University of Agricultural Sciences

Raichur-584 104 Karnataka, India

${ }^{3}$ Directorate of Research, University of Agricultural Sciences Raichur-584 104, Karnataka, India

${ }^{4}$ Directorate of Education, University of Agricultural Sciences Raichur-584 104, Karnataka, India

*Corresponding author

\section{A B S T R A C T}

Keywords

Chickpea, Sprint, Seed treatment

Article Info

Accepted:

15 December 2019

Available Online:

20 January 2020
A laboratory experiment was carried out to study the effect of seed treatment with different fungicides on seed quality at Seed Research and Quality Assurance Laboratory of Seed Unit, University of Agricultural Sciences, Raichur, during 2018-19. The experiment was laid out in completely randomised block design with six treatments that included fungicides at different concentrations and was replicated four times. The results revealed that, among various seed treatments studied, the seeds treated with sprint @ $3.5 \mathrm{~g} \mathrm{~kg}^{-1}$ recorded significantly highest seed quality parameters viz., seed germination $(97 \%)$, shoot length $(15.34 \mathrm{~cm})$, root length $(18.30 \mathrm{~cm})$, total seedling length $(31.91 \mathrm{~cm})$, seedling dry weight (793 mg), seedling vigour index-I (3210) and total dehydrogenase activity (0.94) as compared to untreated seeds $(87 \%, 10.73 \mathrm{~cm}, 14.23 \mathrm{~cm}, 23.61$ $\mathrm{cm}, 706 \mathrm{mg}, 2055$ and 0.73 , respectively) and also showed that seeds treated with Xelora @ $4 \mathrm{ml} \mathrm{kg}^{-1}$ recorded negligible seed infection $(0.00 \%)$ followed by sprint $(1.33 \%)$. Hence, seed treatment of chickpea seeds with Sprint @ $3.5 \mathrm{~g} \mathrm{~kg}^{-1}$ is best to attain high seed quality parameters. 


\section{Introduction}

Pulses constitute an important ingredient in a vegetarian diet and are a rich source of protein, containing nearly twice as much protein as that of cereals and nutritionally balance the protein requirement of the vegetarian population. Hence, they are called 'poor man's meat. India is the largest producer of pulses ( $25 \%$ of global production) and the consumer (27\% of world consumption). Pulses account for around 20 per cent of the area under food grains and contribute around 7-10 per cent of the total food grains production in the country (Anon, 2019). Gram is the most dominant pulse and is the third important pulse winter grown crop in semiarid and arid tropics. It has highly digestible protein $(21.1 \%)$, carbohydrates $(61.5 \%)$ and fats $(4.5 \%)$, relatively free from antinutritional factors. Further, it also accounts for efficient soil enrichment by symbiotic nitrogen fixation and it has the ability to meet more than 70 percent of its nitrogen requirement from symbiotic nitrogen fixation, besides being drought tolerant. In India, chickpea is cultivated in an area of 10.22 million hectares, producing 10.09 million tonnes with average productivity of $967 \mathrm{~kg}$ per hectare. In spite of being the largest pulse producing nation, we are still importing pulses. In the recent past import of pulses increased by $11.3 \%$ during 2017-18 when compared to $5.8 \%$ in 2015-16 (Anon, 2017). Therefore, it is imperative to increase pulse production in the country. This can be achieved by use of quality seed of improved varieties, adoption of integrated crop management practices including seed treatment and other practices.

In recent years, seed treatments have been proving their worth and are becoming standard. Not only fungicide and insecticide seed treatments help prevent the spread of plant diseases and keep insects at bay, but they also offer added convenience, ease of handling, increased root mass, lower use rates and proven protection from day one. The planting value of seed is one of the key factors for proper plant establishment and performance, particularly under moisture stress conditions. One way of improving productivity of chickpea in drought prone area is seed enhancement treatment. Seed treatment is one of the most important developments to help rapid and uniform germination and emergence of seeds and to increase seed tolerance to adverse environmental conditions. To increase the production of Chickpea qualitatively and quantitatively farmers require healthy and quality seeds, with a high percentage of germination and purity. Hence, it is imperative that seeds must be tested before they are sown in the field. Thus this experiment was carried out with the objective to study the effect of seed treatment with different fungicides on seed quality.

\section{Materials and Methods}

The seeds of desi chickpea cv. GBM 2 obtained from Seed Unit, UAS, Raichur. Laboratory studies were carried out in Seed Unit, UAS, Raichur and field experiment was conducted at seed production block of Seed Unit, UAS, Raichur. Field laid in a randomized block design with three replications. The experiment was laid out in completely randomised block design with six treatments that included fungicides at different concentrations viz., $\mathrm{T}_{1}$ : Control, $\mathrm{T}_{2}$ : Thiram 75 WP @ $2 \mathrm{~g} \mathrm{~kg}^{-1}, \mathrm{~T}_{3}$ : Hexaconacole $(5 \%)+$ Captan (70 \%) (Taqat) @ $2 \mathrm{~g} \mathrm{~kg}^{-1}, \mathrm{~T}_{4}$ : Carboxin (37.5 \%) + Thiram (37.5\%) (Vitavax power) @ $2 \mathrm{~g} \mathrm{~kg}^{-1}, \mathrm{~T}_{5}$ : Mancozeb (50 $\%)+$ Carbendazim (25\%) (Sprint) @ $3.5 \mathrm{~g}$ $\mathrm{kg}^{-1}$, T6: Thiophanate Methyl + Pyraclostrobin (Xelora)@ $4 \mathrm{ml} \mathrm{kg}^{-1}$ and was replicated four times. The observations on seed quality parameters viz., seed germination (\%), shoot length, root length, seedling length, seedling 
vigour index, seedling dry weight and dehydrogenase activity were recorded.

Germination test was conducted using four replicates of 100 seeds each in the paper (between paper) medium and incubated in the walk-in germination room. The germination room was maintained at $25 \pm 2 \mathrm{oC}$ temperature and $90 \pm 5 \% \mathrm{RH}$. Germination percentage, seedling length and seedling dry weight was calculated on $8^{\text {th }}$ day. The seedling vigour index was determined by multiplying the percent germination and total seedling length (Abdul-Baki and Anderson, 1973).

The standard blotter method was used to detect the presence of fungi on or in the seeds after incubation. Seed infection percentage was calculated by counting number of seeds that showed prevalence of fungal growth in petri plate after $8^{\text {th }}$ day of incubation $\left(25 \pm 2^{0} \mathrm{C}\right.$ under diurnal conditions) of seeds. ELICO UV-VIS spectrophotometer (model SC-159) using the blue filter at $470 \mathrm{~nm}$ wavelength and methylcellulose was used as blank for obtaining OD value which is reported as dehydrogenase activity (Kittock and Law, 1968).

\section{Results and Discussion}

Seeds are treated with fungicides before sowing to disinfect them from soil-borne or seed-borne pathogenic fungi present on seed surface. It prevents spreading of fungal-borne plant disease and improves seed germination. So, in this experiment different fungicides viz., Thiram, Taqat, Vitavax power, Sprint, Xelora were used to check their efficiency.

Seed treatment with different fungicides showed a significant difference. Among the treatments, seeds treated with mancozeb (50 $\%)+$ carbendazim (25\%) @ $3.5 \mathrm{~g} \mathrm{~kg}^{-1}\left(\mathrm{~T}_{5}\right)$ recorded significantly highest seed germination (97\%) which was on par with $\mathrm{T}_{6}$ (Thiophanate Methyl + Pyraclostrobin) (Xelora) @ $4 \mathrm{ml} \mathrm{kg}^{-1}$. Among all the treatments control $\left(\mathrm{T}_{1}\right)$ recorded minimum germination percentage ( $87 \%)$. Above results are in tune with Pavan (2018) in kabuli chickpea who reported that increase in germination when treated with mancozeb (50 $\%)+$ carbendazim $(25 \%)$ is due to the reason that sprint is composed of micronutrients viz., Zinc ( $\mathrm{Zn})$ and Manganese (Mn), where $\mathrm{Zn}$ helps in the synthesis of tryptophan which is a precursor of indole acetic acid, it also has an active role in the production of an essential growth hormone i.e., auxin which might have helped in the enhancement of mitochondrial activity leading to the formation of high energy compounds and vital biomolecules which were made available during early phase of germination. Similar results were recorded by Seema et al., (2017) in kabuli chickpea and Ingle (2018) in soybean reported that seed dressing with mancozeb $(50 \%)+$ carbendazim (25\%) had recorded highest germination.

Among the different seed treatments with respect to seedling parameters, $\mathrm{T}_{5}$ has shown the highest shoot length, root length and seedling length $(15.34 \mathrm{~cm}, 18.30 \mathrm{~cm}$ and $31.91 \mathrm{~cm})$ respectively. However, seeds treated with $\mathrm{T}_{4}$ and $\mathrm{T}_{6}$ have shown shoot length, root length and seedling length (13.92, 16.75 and 28.17 , respectively) and $(14.75 \mathrm{~cm}$, $17.61 \mathrm{~cm}$ and $29.13 \mathrm{~cm}$, respectively) respectively on par with $\mathrm{T}_{5}$. The lowest seedling parameter viz., shoot length, root length and seedling length $(10.73 \mathrm{~cm}, 14.23$ $\mathrm{cm}$ and $23.61 \mathrm{~cm}$ ) were recorded in control $\left(\mathrm{T}_{1}\right)$. 
Table.1 Effect of seed treatment with different fungicides on seed quality parameters of chickpea $c v$. GBM 2

\begin{tabular}{|c|c|c|c|c|c|c|c|c|}
\hline Treatments & $\begin{array}{c}\text { Germination } \\
(\%)\end{array}$ & $\begin{array}{l}\text { Shoot length } \\
\text { (cm) }\end{array}$ & $\begin{array}{l}\text { Root length } \\
\text { (cm) }\end{array}$ & $\begin{array}{l}\text { Total seedling } \\
\text { length }(\mathrm{cm})\end{array}$ & SVI & $\begin{array}{c}\text { Seed } \\
\text { Infection } \\
(\%)\end{array}$ & $\begin{array}{l}\text { Seedling } \\
\text { dry weight } \\
(\mathrm{mg})\end{array}$ & $\begin{array}{l}\text { Total } \\
\text { Dehydrogenase } \\
\text { activity (ODV) }\end{array}$ \\
\hline $\mathbf{T}_{1}$ & 87 & 10.73 & 14.23 & 23.61 & 2055 & 29.33 & 706 & 0.73 \\
\hline $\mathbf{T}_{2}$ & 89 & 11.77 & 15.20 & 24.57 & 2627 & 20.00 & 730 & 0.77 \\
\hline $\mathbf{T}_{3}$ & 90 & 10.90 & 14.87 & 24.21 & 2448 & 9.33 & 740 & 0.78 \\
\hline $\mathbf{T}_{4}$ & 93 & 13.92 & 16.75 & 28.17 & 2968 & 9.33 & 773 & 0.87 \\
\hline $\mathbf{T}_{5}$ & 97 & 15.34 & 18.30 & 31.91 & 3210 & 1.33 & 793 & 0.94 \\
\hline$T_{6}$ & 95 & 14.75 & 17.61 & 29.13 & 3113 & 0.00 & 756 & 0.89 \\
\hline Mean & 91 & 12.90 & 16.16 & 26.93 & 2736 & 11.55 & 749 & 0.83 \\
\hline S. Em \pm & 0.47 & 0.56 & 0.51 & 0.93 & 56.28 & 2.88 & 43.92 & 0.01 \\
\hline CD@1\% & 2.04 & 2.41 & 2.18 & 4.02 & 243.12 & 12.44 & NS & 0.06 \\
\hline
\end{tabular}

NS: Non-significant

$\mathrm{T}_{1}$ : Control

$\mathrm{T}_{2}$ : Thiram 75 WP @ $2 \mathrm{~g} \mathrm{~kg}^{-1}$

$\mathrm{T}_{3}$ : Hexaconacole $(5 \%)+$ Captan $(70 \%)$ (Taqat) @ $2 \mathrm{~g} \mathrm{~kg}^{-1}$

$\mathrm{T}_{4}$ : Carboxin $(37.5 \%)+$ Thiram $(37.5 \%)$ (Vitavax power)@ $2 \mathrm{~g} \mathrm{~kg}^{-1}$

$\mathrm{T}_{5}$ : Mancozeb (50\% + Carbendazim (25\%) (Sprint) @ $3.5 \mathrm{~g} \mathrm{~kg}^{-1}$

$\mathrm{T}_{6}$ : Thiophanate Methyl + Pyraclostrobin (Xelora) @ $4 \mathrm{ml} \mathrm{kg}^{-1}$ 
Fig.1 Effect of seed treatment with different fungicides on seed germination and seedling vigour index
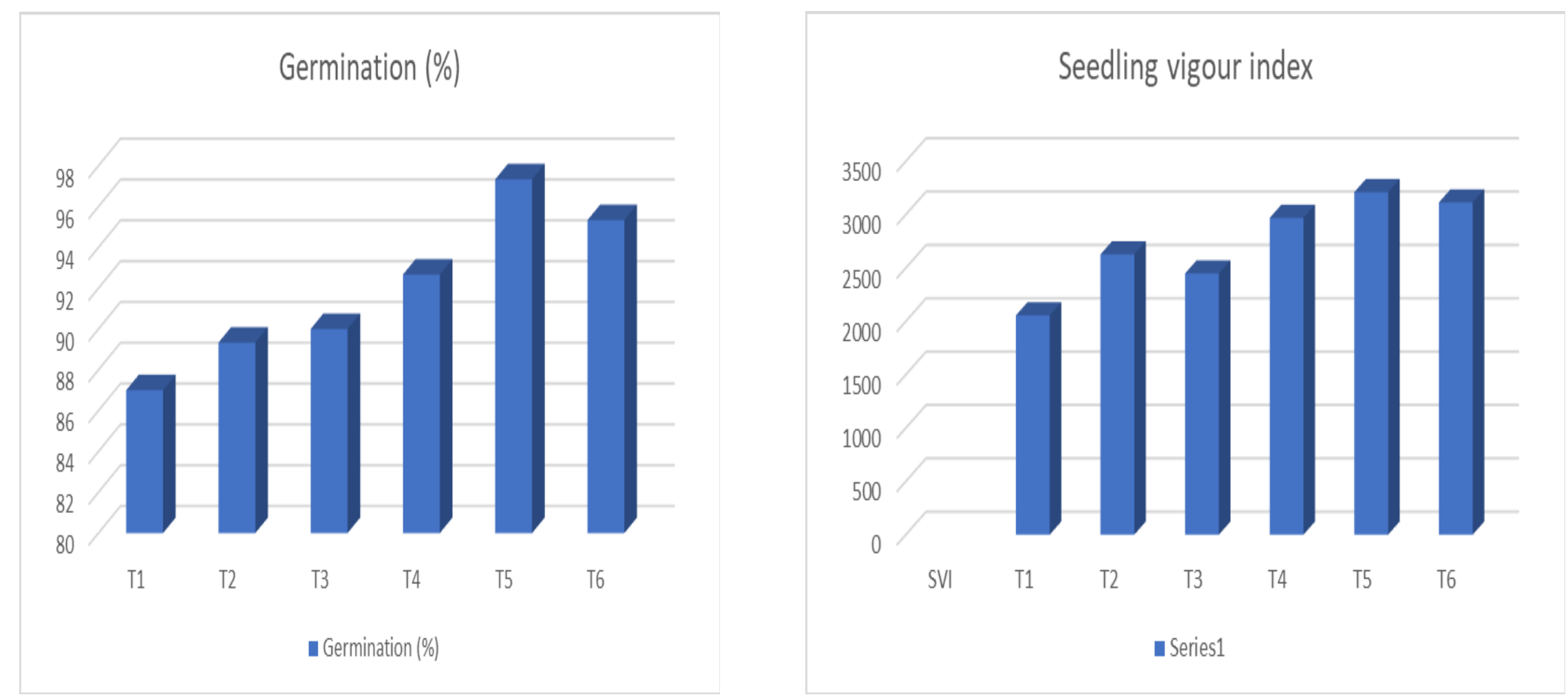

\section{$\mathrm{T}_{1}$ : Control}

$\mathrm{T}_{2}$ : Thiram 75 WP @ $2 \mathrm{~g} \mathrm{~kg}^{-1}$

$\mathrm{T}_{3}$ : Hexaconacole (5\%) + Captan (70\%) (Taqat) @ $2 \mathrm{~g} \mathrm{~kg}^{-1}$

$\mathrm{T}_{4}$ : Carboxin (37.5\%) + Thiram (37.5\%) (Vitavax power) @ $2 \mathrm{~g} \mathrm{~kg}^{-1}$

$\mathrm{T}_{5}$ : Mancozeb (50\% + Carbendazim (25\%) (Sprint) @ $3.5 \mathrm{~g} \mathrm{~kg}^{-1}$

$\mathrm{T}_{6}$ : Thiophanate Methyl + Pyraclostrobin (Xelora) @ $4 \mathrm{ml} \mathrm{kg}^{-1}$ 
Fig.2 Effect of seed treatment with different fungicides on seed infection (\%) and dehydrogenase activity
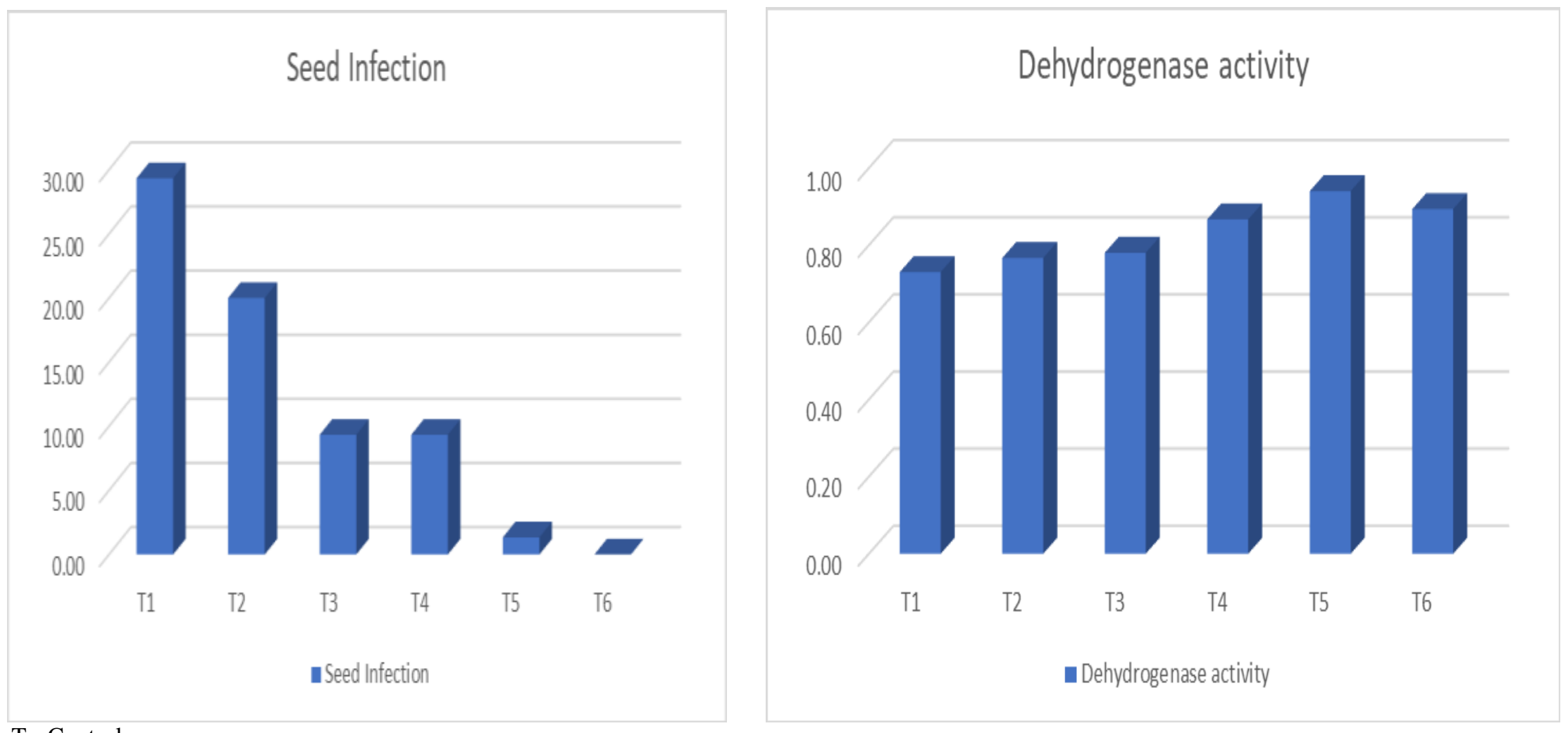

$\mathrm{T}_{1}$ : Control

$\mathrm{T}_{2}$ : Thiram 75 WP @ $2 \mathrm{~g} \mathrm{~kg}^{-1}$

$\mathrm{T}_{3}$ : Hexaconacole $(5 \%)+$ Captan $(70 \%)$ (Taqat) @ $2 \mathrm{~g} \mathrm{~kg}^{-1}$

$\mathrm{T}_{4}$ : Carboxin (37.5\%) + Thiram (37.5\%) (Vitavax power)@ $2 \mathrm{~g} \mathrm{~kg}^{-1}$

$\mathrm{T}_{5}$ : Mancozeb (50\% + Carbendazim (25\%) (Sprint) @ $3.5 \mathrm{~g} \mathrm{~kg}^{-1}$

$\mathrm{T}_{6}$ : Thiophanate Methyl + Pyraclostrobin (Xelora) @ $4 \mathrm{ml} \mathrm{kg}^{-1}$ 
The probable reason for increased root and shoot length may be due to the residual systemic action of zinc and manganese present in sprint which contributed in increasing the metabolic activity of enzymes helping in excess cell division, enlargement and elongation of root length making root surface to absorb more nutrient from media making it easier for plumule meristem to grow with elongation and enlargement of shoot cells. The results are in confirmation with the Seema et al., (2017) in kabuli chickpea and Anitha et al., (2013) in soybean.

Among different fungicidal treatments, $\mathrm{T}_{5}$ has shown the highest seedling vigour index (3210) when compared to control $\left(\mathrm{T}_{1}\right)$ which have recorded minimum seedling vigour index (2055). However, treatments $\left(\mathrm{T}_{4}\right)$ and $\left(\mathrm{T}_{6}\right)$ have shown the seedling vigour index (2968 and 3113 respectively) on par with the T5.

The above results are in tune with the Pavan et al., (2018) in Kabuli chickpea reported that seedling vigour index is said to be the product of seed germination and total seedling length (root + shoot length) and ultimately resulted in higher seed vigour. Similar results are reported by Seema et al., (2017) and Pavan et al., (2018) in Kabuli chickpea who reported that seeds treated with mancozeb $(50 \%)+$ carbendazim (25\%) have recorded highest seedling vigour index.

The significant variation was observed for seed mycoflora (viz., Aspergillus niger) among the treatments. Significantly lowest seed mycoflora viz., Aspergillus niger was recorded in $\mathrm{T}_{6}(0 \%)$ followed by $\mathrm{T}_{5}(1.33 \%)$. Among treatments highest seed mycoflora were recorded in control T1 (29.33\%).The above results are in tune with Mehilal (2017) who reported that potato tubers treated with Thiophanate methyl + Pyraclostrobin recorded 83.7 per cent decrease in disease incidence. This might be due to the reason that protectant fungicides prevent only spore germination, while the systemic fungicides work by inhibiting the development of fungi probably by interfering with spindle formation at mitosis (cell division) inhibit fungal growth.

The data presented indicated that fungicidal treatments had no significant effect on the seedling dry weight. However, $\mathrm{T}_{5}$ (mancozeb (50\% + carbendazim (25\%) (Sprint) @ $3.5 \mathrm{~g}$ $\mathrm{kg}^{-1}$ has recorded highest seedling dry weight (793 mg) when compared to control $\mathrm{T}_{1}$ (706 $\mathrm{mg}$ ). Lower seedling length and dry weight in control during storage may be attributed to ageing effects, leading to depletion of food reserves and decline in synthetic activity of the embryo apart from death of seeds because of fungal invasion (Gupta et al., 1993). As there was better seedling growth, seedling dry weight was also high.

Data presented in the Table 1 indicated that the treatment, $\mathrm{T}_{5}$ recorded significantly highest dehydrogenase activity (0.94) which was on par with $\mathrm{T}_{6}$ (0.89), while lowest dehydrogenase activity (0.73) was recorded in control $\left(\mathrm{T}_{1}\right)$.

Above results are in line with the findings of Shashibhaskar (2009) in tomato, reported that seeds treated with fungicide carbendazim showed highest dehydrogenase activity (0.721).

They reported that higher seedling vigour index and low per cent of seed infection might have resulted in higher dehydrogenase activity. Similar findings were reported by Sharanamma (2002) in chilli.

The results of this study concluded that seeds treated with Sprint (Mancozeb $50 \%+$ Carbendazim 25\%@3.5 g kg-1 fungicide was found to be better for chickpea as it recorded highest seed quality parameters in storage compared to untreated seeds. 


\section{References}

Abdul-Baki, A. A. and Anderson, J. D., 1973, Vigour determination in soybean by multiple criteria. Crop Sci., 13: 630633.

Anitha,U., Mummigatti, V. and Punith Kumar, C. H., 2013, Effect of organic and inorganic seed priming on soybean germination and yield parameters. Biolife., 1 (4): 23-30.

Anonymous, 2017, http://dpd.gov.in/

Anonymous, 2019, vikaspedia.com.

Gupta, I. J., Schmitthenner, A. E. and Mc Donald, M. B., 1993, Effect of storage fungi on seed vigour of soybean. Seed Sci. Tech., 21: 581-591.

Ingle, Y. V., Zope, A. V., Wasule, D. L., Dandge, M. S. and Patil, P. V., 2018, Effect of seed dressing on germination and root rot of soybean. Intl. J. of Chem. Studies., 6(1): 653-655.

Kittock, P. A. and Law, A. G., 1968, Relationship of seedling vigour to respiration and tetrazolium chloride reduction of germinating wheat seeds. Agron. J., 60: 286-288.

Mehilal, Saurabh, Yadav and Subhash Chand, 2017, Thiphanate methyl 45\% + pyraclostrobin 5\% FS: A new molwcule for potato tubers treatment against black scurf disease caused by Rhicoctonia solani. Indian J. Pl. Protection., 45(2): 177-180.

Pavan Shinde, Ravi Hunje, Uppar, D. S. and Potdar, M. P., 2018, Effect of seed priming on seed quality of resultant seed in Kabuli chickpea (Cicer arietinum L.) varieties. Intl. J. Chemical Studies, 6(5): 3193-3197.

Seema Beedi, Basave Gowda, Sangeeta, I. Macha, Savitha, A. S. and Vijaykumar Kurnallikar, 2017, Effect of seed priming on germination percentage, shoot length, root length, seedling vigour index, moisture content and electrical conductivity in storage of kabuli chickpea $c v$. MNK - 1 (Cicer arietinum L.). J. Pharma. Phytochemistry, 7(1): 2005-2010.

Sharanamma, B., 2002, Effect of provenance, seed treatment and containers on storability of chilli seeds. M. Sc. (Agri.) Thesis, Univ. Agric. Sci., Dharwad (India).

Shashibhaskar, M. S., Vasudevan, S. N., Kurdikeri, M. B., Ravikumar, R. L. and Basavaraj, N., 2008, Influence of seed pelleting on storability of tomato (Lycopersicum esculentum Mill.). Karnataka J. Agric. Sci., 22(5): 10971103.

\section{How to cite this article:}

Basave Gowda, Rajashekar Kasam, S. R. Doddagoudar, Vijaykumar Kurnalliker, Channabasavanna and Ravi, A. S. M. V. 2020. Influence of Seed Treatment with Fungicides on Seed Quality of Chickpea cv. GBM 2. Int.J.Curr.Microbiol.App.Sci. 9(01): 602-609. doi: https://doi.org/10.20546/ijcmas.2020.901.065 